Research

\title{
Concurrent chemo-radiotherapy following neoadjuvant chemotherapy in locally advanced breast cancer
}

\author{
Alberto Alvarado-Miranda1, Oscar Arrieta*1, Carlos Gamboa-Vignolle2, \\ David Saavedra-Perez ${ }^{1}$, Rafael Morales-Barrera ${ }^{1}$, Enrique Bargallo-Rocha ${ }^{3}$, \\ Juan Zinser-Sierra ${ }^{1}$, Victor Perez-Sanchez ${ }^{4}$, Teresa Ramirez-Ugalde ${ }^{3}$ and \\ Fernando Lara-Medina ${ }^{1,3}$
}

\begin{abstract}
Address: ${ }^{1}$ Department of Medical Oncology, Instituto Nacional de Cancerologia, Mexico City, Mexico, ${ }^{2}$ Department of Radiotherapy, Instituto Nacional de Cancerologia, Mexico City, Mexico, ${ }^{3}$ Department of Breast Tumors, Instituto Nacional de Cancerologia, Mexico City, Mexico and ${ }^{4}$ Department of Pathology, Instituto Nacional de Cancerologia, Mexico City, Mexico

Email: Alberto Alvarado-Miranda - alberalvarmir@yahoo.com.mx; Oscar Arrieta* - ogar@servidor.unam.mx; Carlos Gamboa-

Vignolle - cswgamboa@yahoo.com; David Saavedra-Perez - seelowen@msn.com; Rafael Morales-Barrera - ramoba2000@yahoo.com.mx;

Enrique Bargallo-Rocha - ebargallo@yahoo.com; Juan Zinser-Sierra - juanwzinser@yahoo.com.mx; Victor Perez-

Sanchez - vperezs@incan.edu.mx; Teresa Ramirez-Ugalde - sisug@hotmail.com; Fernando Lara-Medina - fuliseslara@yahoo.com.mx

* Corresponding author
\end{abstract}

Published: I I July 2009

Radiation Oncology 2009, 4:24 doi:10.1186/1748-717X-4-24

This article is available from: http://www.ro-journal.com/content/4/I/24

(C) 2009 Alvarado-Miranda et al; licensee BioMed Central Ltd.

This is an Open Access article distributed under the terms of the Creative Commons Attribution License (http://creativecommons.org/licenses/by/2.0), which permits unrestricted use, distribution, and reproduction in any medium, provided the original work is properly cited.
Received: 15 May 2009

Accepted: II July 2009

\begin{abstract}
Background: Despite broad advances in multimodal treatment of locally advanced breast cancer (LABC), 30 to $40 \%$ of patients develop loco-regional relapse. The aim of this study was to analyze in a retrospective manner the effectiveness of concurrent chemo-radiotherapy (CCRTh) after neoadjuvant chemotherapy (NCT) in patients with LABC.

Methods: One hundred twelve patients with LABC (stage IIB-IIIB) were treated with NCT (5-fluorouracil 500 $\mathrm{mg} / \mathrm{m}^{2}$, doxorubicin $50 \mathrm{mg} / \mathrm{m}^{2}$, and cyclophosphamide $500 \mathrm{mg} / \mathrm{m}^{2}(\mathrm{FAC})$, or doxorubicin $50 \mathrm{mg} / \mathrm{m}^{2}$ and cyclophosphamide $500 \mathrm{mg} / \mathrm{m}^{2}$ (AC) IV in four 2I-day courses) followed by CCRTh (60 Gy breast irradiation and weekly mitomycin $5 \mathrm{mg} / \mathrm{m}^{2}$, 5 -fluorouracil $500 \mathrm{mg} / \mathrm{m}^{2}$, and dexamethasone $16 \mathrm{mg}$, or cisplatin $30 \mathrm{mg} / \mathrm{m}^{2}$, gemcitabine $100 \mathrm{mg} / \mathrm{m}^{2}$ and dexamethasone $16 \mathrm{mg}$ ), and 6-8 weeks later, surgery and two additional courses of FAC, AC, or paclitaxel $90 \mathrm{mg} / \mathrm{m}^{2}$ weekly for 12 weeks, and in case of estrogen-receptor positive patients, hormonal therapy.

Results: Stages IIB, IIIA and -B were 21.4, 42.9, and 35.7\%, respectively. Pathological complete response (PCR) in the breast was $42 \%(95 \% \mathrm{Cl}, 33.2-50.5 \%)$ and, $29.5 \%$ (95\% Cl, 2I.4-37.5\%) if including both the breast and the axillary nodes. Multivariate analysis showed that the main determinant of $\mathrm{pCR}$ was negative estrogen-receptor status (HR $=3.8 ; 95 \% \mathrm{Cl}, 1.5-9 ; p=0.016)$. The 5-year disease-free survival (DFS) was $76.9 \%(95 \% \mathrm{Cl}, 68.2-$ 84.7\%). No relationship between PCR and DFS was found. Multivariate analysis demonstrated that the main DFS determinant was clinical stage (IIB and IIIA vs. IIIB, HR $=3.1 ; 95 \% \mathrm{Cl}, 1.02-9.74 ; p=0.04$ ). Only one patient had local recurrence. Five-year overall survival was $84.2 \%(95 \% \mathrm{Cl}, 75-93.2 \%)$. The toxicity profile was acceptable.
\end{abstract}

Conclusion: This non-conventional multimodal treatment has good loco-regional control for LABC. Randomized clinical trials of preoperative CCRTh following chemotherapy, in patients with LABC are warranted. 


\section{Background}

Breast cancer is the second leading cause of cancer death among women in developed countries and in Mexico $[1,2]$. In Mexico, only a small percentage of women have regular mammography screening; therefore the proportion of patients with locally advanced disease at diagnosis is high. In 2003, only 5-10\% of newly diagnosed cases in Mexico were clinical stages 0 or I [2]. In fact, nearly $70 \%$ of breast cancer cases of patients seen at the Instituto Nacional de Cancerología (INCan: a cancer-referral teaching hospital for adult patients, located in Mexico City) are stage IIB-IIIB, locally advanced breast cancer (LABC, 6th edition of the AJCC Cancer Staging) $[3,4]$.

Current treatment of LABC requires a combination of systemic chemotherapy (CT), surgery, and radiotherapy (RT) [5]. Between six and eight courses of anthracycline- and taxane-based regimens administered sequentially or in combination are now recommended, and CT should be followed by segmental or modified radical mastectomy for operable tumors. Patients with inoperable tumors after maximal CT (i.e., taxane if initial therapy was anthracycline-based) could proceed to definitive RT. Patients treated with surgery should receive post-operative RT to minimize the risk of local recurrence. In addition, women with hormone-receptor-positive tumors should receive hormonal therapy (HT) [5].

However, only $10-20 \%$ of patients with LABC achieve clinical complete response, and 50-60\%, partial response [6-8]. Pathological complete response (pCR) rate in LABC is poor, $8-12 \%$, and often does not correlate with clinical response [6,8-11]. Approximately, 30-40\% of patients with LABC develop loco-regional relapse (LRR) [8].

Despite improvements in local control rates and overall outcomes with current therapy, 5-year survival for LABC remains low (50\% vs. $87 \%$ for stage I) [12]. Moreover, concurrent chemo-radiotherapy (CCRTh) with anthracycline drugs is theoretically more toxic; therefore, in patients with LABC, this treatment modality has not been widely used. However, CCRTh has successfully improved both local control and overall survival (OS) in other cancers such as esophageal, lung, head and neck, and cervix [13-16].

The aim of this study was to determine disease-free survival (DFS), pathologic complete response (pCR) and associated factors using a multimodal therapy (neoadjuvant chemotherapy followed by concurrent CCRTh, surgery, and CT) in patients with locally advanced breast cancer.

\section{Methods}

\section{Patients and samples}

From January 2000 to December 2003, patients seen at the INCan Department of Breast Tumors with diagnosis of breast cancer confirmed by histopathology who presented loco regional disease (stages IIB, IIIA and $-\mathrm{B}$, according to the 6 th edition of the American Joint Committee on Cancer TNM classsification and staging system and evaluated by thoracic computed tomography (CT) scans, bone scinthigraphy and/or PET-CT) [4], without clinical response (according to the attending physician, based on an increase in the breast tumor and/or pathologic axillary lymph node diameters $\geq 50 \%$ ) after completion of anthracycline-containing neoadjuvant chemotherapy, and without evidence of distant metastases at diagnosis were enrolled; this primary CT was followed by concurrent chemo-radiotherapy (CCRTh), modified radical mastectomy, and adjuvant systemic treatment. Exclusion criteria comprised other clinical stages from IIB, IIIA, and -B, Phyllodes tumour as histological diagnosis, and treatment variations. Biopsies were examined and classified by a pathologist specialized in this tumor type. The Breast Cancer Classification proposed by the World Health Organization was employed to classify each biopsy. We utilized the Scarff-Bloom-Richardson (SBR) scale that is based on nuclear pleomorphism and mitotic count, to stratify each tumor's tissue differentiation. Hormonal status was obtained by immunohistochemistry on sections of formalin-fixed, paraffin-embedded tissue, from incisional biopsies and subsequent surgical specimens.

\section{Treatment}

Neoadjuvant CT was instituted in four 21-days courses. The following two treatment schedules were utilized: a) 5fluorouracil $\left(500 \mathrm{mg} / \mathrm{m}^{2}\right)$, adriamycin $\left(50 \mathrm{mg} / \mathrm{m}^{2}\right)$, and cyclophosphamide $\left(500 \mathrm{mg} / \mathrm{m}^{2}\right)$ (FAC), or b) adriamycin $\left(50 \mathrm{mg} / \mathrm{m}^{2}\right.$ ) and cyclophosphamide $\left(500 \mathrm{mg} / \mathrm{m}^{2}\right)$ (AC). CCRTh after the previously mentioned regimen was as follows: RT 60 Gy (3-D CT-based simulation) to the wholebreast and nodal areas divided into 50 Gy in 5 weeks plus boost to palpable residual disease with a 10 Gy electron beam in 1 week, and CT based on mitomycin C (5 mg/ $\left.\mathrm{m}^{2}\right)$, 5-fluorouracil $\left(500 \mathrm{mg} / \mathrm{m}^{2}\right)$, and dexamethasone $(16 \mathrm{mg})$, or cisplatin $\left(30 \mathrm{mg} / \mathrm{m}^{2}\right)$, gemcitabine $(100 \mathrm{mg} /$ $\mathrm{m}^{2}$ ) and dexamethasone (16 mg), weekly during RT (six cycles in total). Radiation Therapy Oncology Group (RTOG) scale was used for toxicity assessment.

Modified radical mastectomy and axillary lymph-node dissection were performed post-CCRTh. Six to eight weeks after surgery, patients received adjuvent systemic treatment with FAC or AC for two additional courses, as previously described. Patients in another subgroup were treated with paclitaxel at a dose of $90 \mathrm{mg} / \mathrm{m}^{2}$ weekly for 12 weeks. Adjuvant hormonal treatment was administered to patients with positive tissue hormonal receptors.

\section{Response}

Pathological complete response (pCR) was defined as no presence of tumor or microscopic disease (presence of 
microscopic foci in histologic sample) in breast (pCRB) samples, resected axillary (pCRA) lymph nodes and both sites (PCR). Pathological response was classified as residual if any tumour was present.

\section{Statistical analysis}

For descriptive purposes, continuous variables were summarized as arithmetic means and standard deviations (SDs, errors), and categorical variables comprised relative frequencies and proportions. Inferential comparisons were performed with the Student $t$ test or the Mann-Whitney $U$ test according to the distribution (normal and nonnormal) determined by the Kolmogorov-Smirnov test. The Chi-squared or Fisher exact test was utilized to compare clinical variables and pCR. Logistical regression analysis was employed in significant (or near significant; $p=$ $0.1)$ variables. Disease-free (DFS) and overall survivals (OS) were analyzed with the Kaplan-Meier technique, and comparisons among subgroups were performed with a log-rank test. All variables were dichotomized for survival analysis. Adjustment of potential confounders was conducted by log-rank analysis stratification and by Cox proportional hazards regression multivariate analysis. All tests were two-sided, and the significance value was set at $p=0.05$. SPSS (version 10.0; SPSS, Inc., Chicago, IL, USA) and STATA (StataCorp, College Station, TX) software packages were employed for data analysis.

\section{Results}

\section{Patients and Samples}

Between January 2000 and December 2003, 112 patients met the selection criteria for this study. Mean age was 50 \pm 11 years, and median tumour size was $5 \pm 1.56 \mathrm{~cm}$. Patients with tumor at stages T2, -3 and -4 represented $19.6,44.6$ and $35.7 \%$ of cases, respectively. Thus, patients were in clinical stages IIB, IIIA, and -B were 21.4, 42.9, and $35.7 \%$, respectively (Table 1 ). All neoplasms were infiltrating ductal carcinoma. ER-positive expression was found in $42.9 \%$, and in $41.1 \%$ for PgR. Low/moderate histological grade was 40.2, while and high grade stood at $59.8 \%$. Human epithelial growth factor receptor 2 (HER2) expression was not included in data analysis because only two patients $(1.7 \%)$ were positive. Post-surgical systemic treatment was based on anthracycline in $48.2 \%$ and on taxane drugs in $51.8 \%$ of patients (Table 1 ).

\section{Pathological Complete Response}

Pathological response was independently assessed in the primary site and in the axillary lymph nodes. In the breast, pCRB was present in 42\% (95\% Confidence interval [95\% $\mathrm{CI}$, 33.2-50.5), microscopic disease in $27.7 \%$ (95\% CI, 19.2-36.8), and residual disease in 30.4\% (95\% CI, 25.338.9) of patients, while in the axilla, pCRA was found in $58 \%(95 \% \mathrm{CI}, 52.8-65.1)$ and persistent disease in $42 \%$ (95\% CI, 30.2-47.3) of patients. At both sites (breast and axilla), pCR was 29.5\% (95\% CI, 21.4-37.5) (Table 2).
Table I: Baseline patient characteristics

\begin{tabular}{|c|c|c|}
\hline $\begin{array}{l}\text { Variable } \\
N=1 / 2\end{array}$ & Median \pm SE & $\begin{array}{c}\text { Number } \\
(\%)\end{array}$ \\
\hline Age (years) & $50 \pm 11$ & \\
\hline $\begin{array}{l}\text { Tumor size } \\
\text { (cm) }\end{array}$ & $\begin{array}{c}5 \pm 1.56 \\
\text { Mean, } 3.93\end{array}$ & \\
\hline \multicolumn{3}{|l|}{ Clinical T stage* } \\
\hline $\mathrm{T} 2$ & & $22(19.6)$ \\
\hline T3 & & $50(44.6)$ \\
\hline T4 & & $40(35.7)$ \\
\hline \multicolumn{3}{|l|}{ Clinical $\mathbf{N}$ stage* } \\
\hline $\mathrm{NI}$ & & $55(49.1)$ \\
\hline N2 & & $56(50)$ \\
\hline N3 & & I (0.9) \\
\hline \multicolumn{3}{|l|}{ Clinical stage* } \\
\hline IIB & & $24(21.4)$ \\
\hline IIIA & & $48(42.9)$ \\
\hline IIIB & & $40(35.7)$ \\
\hline \multicolumn{3}{|l|}{ Histological grade $\dagger$} \\
\hline Low/moderate & & $45(40.2)$ \\
\hline High & & $67(59.8)$ \\
\hline \multicolumn{3}{|l|}{ Estrogen receptors } \\
\hline Positive & & $48(42.9)$ \\
\hline Negative & & $64(57.1)$ \\
\hline \multicolumn{3}{|l|}{ Progesterone receptors } \\
\hline Positive & & $46(4 I . I)$ \\
\hline Negative & & $66(58.9)$ \\
\hline \multicolumn{3}{|l|}{ Treatment after CCRTh } \\
\hline Anthracycline & & $54(48.2)$ \\
\hline Taxanes & & $58(51.8)$ \\
\hline \multicolumn{3}{|c|}{$\begin{array}{l}\text { Abbreviations: SE = standard error; CCRTh = concurrent chemo- } \\
\text { radiotherapy. } \\
* 6 \text { th edition of the American Joint Committee on Cancer TNM } \\
\text { classification } \\
\text { and staging system. } \\
\text { † Scarff-Bloom-Richardson (SBR) scale. }\end{array}$} \\
\hline
\end{tabular}

Table 3 shows the relationship between pCR and clinicopathological factors. Multivariable analysis demonstrated that the main determinant of pCR was negative ER status $(\mathrm{HR}=3.8 ; 95 \% \mathrm{CI}, 1.5-9 ; p=0.016)$.

\section{Outcomes}

Mean follow-up was 43 months (range 7-125 months). Median DSF has not been achieved. Five-year DFS was 76.9\% (95\% CI, 68.2-84.7\%). No relationship between pCR and DFS was found. As independent factors, clinical stages IIB and IIIA were associated with a longer diseasefree survival ( $\mathrm{HR}=3.1 ; 95 \% \mathrm{CI}, 1.02-9.74 ; p=0.04)$ as compared to clinical stage IIIB (Table 4). Only one patient had local recurrence. Tumor relapse occurred in 12.5, 3.6, 
Table 2: Frequency of pathological-complete response at primary site and axilla

\begin{tabular}{cc}
\hline $\begin{array}{c}\text { Primary site/axilla } \\
\mathbf{N}=\mathbf{~ I ~} \mathbf{2}\end{array}$ & $\begin{array}{c}\text { Frequency } \\
\text { (\%) }\end{array}$ \\
\hline Negative/negative & 29.5 \\
Negative/positive & 12.5 \\
Positive/negative & 28.6 \\
Positive/positive & 29.5 \\
\hline
\end{tabular}

2.7, and $1.8 \%$ as bone, lung, liver and brain metastasis, respectively. Three patients had more than one recurrence site. OS at 5 years was $84.2 \%$ (95\% CI, 75-93.2\%). Toxicity exhibited during CCRTh was as follows: grade 1-2 neutropenia in $32.2 \%$, grade $1-2$ anemia in $5.2 \%$, and grade 3 radioepithelitis in $22.4 \%$ of patients.

\section{Discussion}

Use of neoadjuvant systemic CT and post-mastectomy RT has become standard for patients with LABC because this treatment course improves prognosis substantially and enhances the possibility of surgery $[7,17,18]$. Advances in neoadjuvant systemic CT for LABC include not only earlier treatment of sub-clinical distant micrometastases and primary-tumour downstaging, but also the possibility of in vivo assessment of response to specific systemic agents. Thus, it is not only rational, but also current practice, to apply this approach in inoperable LABC [19]. However, the magnitude of benefit from neoadjuvant CT on survival in breast cancer remains unclear due to the few comparative trials conducted specifically on LABC [19]. Comparative trials of neoadjuvant $v$ s. adjuvant CT in primary operable breast cancer demonstrate equivalent survival outcomes [7]. Despite multimodal therapy improvements in LABC, $11-30 \%$ of patients develop local relapse $[5,20]$. Moreover, poor reponse to neoadjuvant CT is known to be associated with a higher probability of loco-regional recurrence (LRR) [20]. In our study, no patient responded to neoadjuvant CT; thus, patients presented a high risk for LRR. Additionally, approximately $60 \%$ were ER-negative, which represents an additional

Table 3: Relationship between pathological-complete response at breast and axilla with clinico-pathological factors

\begin{tabular}{|c|c|c|c|}
\hline $\begin{array}{l}\text { Variable } \\
N=112\end{array}$ & $\begin{array}{c}\text { PCR } \\
\%(95 \% \mathrm{Cl})\end{array}$ & $\begin{array}{c}\text { Univariate analysis } \\
p\end{array}$ & $\begin{array}{c}\text { Multivariate analysis } \\
\text { HR }(95 \% \mathrm{Cl}) \\
\mathbf{p}\end{array}$ \\
\hline Age (years) & & 0.204 & \\
\hline$>50$ & $64(54-74)$ & & \\
\hline$<50$ & $75(67-83)$ & & \\
\hline Clinical T stage* & & 0.218 & \\
\hline $\mathrm{T} 2$ & $54(45-62)$ & & \\
\hline $\mathrm{T} 3$ & $72(64-80)$ & & \\
\hline $\mathrm{T} 4$ & $75(67-83)$ & & \\
\hline Clinical N stage* & & 0.072 & \\
\hline NI & $59(5 \mathrm{I}-67)$ & & \\
\hline N2/N3 & $78(70-85)$ & & \\
\hline Clinical stage* & & 0.656 & \\
\hline IIB & $66(58-74)$ & & \\
\hline IIIA & $66(58-74)$ & & \\
\hline IIIB & $75(67-83)$ & & \\
\hline Estrogen receptors & & 0.002 & $3.8(0.149-0.087) 0.016$ \\
\hline Negative & 81 (74-88) & & \\
\hline Positive & $54(45-63)$ & & \\
\hline Progesterone receptors & & 0.090 & I.I (0.39I-3.57I) 0.767 \\
\hline Negative & $75(67-83)$ & & \\
\hline Positive & $60(52-68)$ & & \\
\hline Histological grade $\dagger$ & & 0.06 & $0.5(0.244-1.038) 0.063$, \\
\hline Low/moderate & $60(52-68)$ & & \\
\hline High & $76(68-84)$ & & \\
\hline
\end{tabular}

Abbreviations: $\mathrm{pCR}=$ pathological complete response; $95 \% \mathrm{Cl}=95 \%$ confidence interval; $\mathrm{HR}=$ hazard ratio.

$* 6$ th edition of the American Joint Committee on Cancer TNM classification and staging system.

† Scarff-Bloom-Richardson (SBR) scale. 
Table 4: Relationship between disease-free survival with clinico-pathological factors

\begin{tabular}{|c|c|c|c|c|c|}
\hline $\begin{array}{l}\text { Variable } \\
N=1 / 2\end{array}$ & $\begin{array}{l}\text { I-year DFS } \\
\text { (months } \pm \text { SD) }\end{array}$ & $\begin{array}{l}\text { 2-year DFS } \\
\text { (months } \pm \text { SD) }\end{array}$ & $\begin{array}{l}\text { 5-year DFS } \\
\text { (months } \pm \text { SD) }\end{array}$ & $\begin{array}{c}\text { Univariate analysis } \\
P\end{array}$ & $\begin{array}{c}\text { Multivariate analysis } \\
\text { HR }(95 \% \mathrm{Cl}) \\
\text { P }\end{array}$ \\
\hline Age (years) & & & & 0.09 & \\
\hline$>50$ & $92 \pm 3$ & $82 \pm 5$ & $82 \pm 5$ & & \\
\hline$<50$ & $96 \pm 2$ & $94 \pm 2$ & $92 \pm 3$ & & \\
\hline Clinical T stage* & & & & 0.05 & \\
\hline T2 & $90 \pm 6$ & $86 \pm 7$ & $86 \pm 7$ & & \\
\hline T3 & $98 \pm 2$ & $96 \pm 2$ & $96 \pm 2$ & & \\
\hline $\mathrm{T} 4$ & $87 \pm 5$ & $82 \pm 6$ & $78 \pm 6$ & & \\
\hline Clinical N stage* & & & & 0.79 & \\
\hline NI & $92 \pm 3$ & $90 \pm 4$ & $90 \pm 4$ & & \\
\hline N2/N3 & $92 \pm 3$ & $87 \pm 4$ & $84 \pm 5$ & & \\
\hline Clinical stage* & & & & 0.03 & $3.1(1.02-9.74) 0.0406$, \\
\hline IIB/IIIA & $95 \pm 2$ & $93 \pm 3$ & $93 \pm 3$ & & \\
\hline IIIB & $87 \pm 5$ & $82 \pm 6$ & $78 \pm 6$ & & \\
\hline Estrogen receptors & & & & 0.012 & $0.3(0.91-1.22) 0.97$, \\
\hline Negative & $92 \pm 3$ & $85 \pm 4$ & $83 \pm 4$ & & \\
\hline Positive & $97 \pm 2$ & $93 \pm 3$ & $93 \pm 3$ & & \\
\hline Histological grade $\dagger$ & & & & 0.04 & $3.5(0.79-16.28) 0.98$, \\
\hline Low/moderate & 100 & $97 \pm 2$ & $94 \pm 3$ & & \\
\hline High & $91 \pm 3$ & $83 \pm 4$ & $83 \pm 4$ & & \\
\hline Pathological response & & & & 0.56 & \\
\hline pCR/microscopic & $92 \pm 3$ & $88 \pm 3$ & $86 \pm 4$ & & \\
\hline Residual & $94 \pm 4$ & $91 \pm 4$ & $91 \pm 4$ & & \\
\hline
\end{tabular}

Abbreviations: DFS = disease-free survival; $\mathrm{SD}=$ standard deviation; $\mathrm{HR}=$ Hazard ratio; $95 \% \mathrm{Cl}=95 \%$ confidence interval.

* 6th edition of the American Joint Committee on Cancer TNM classification and staging system.

† Scarff-Bloom-Richardson (SBR) scale.

risk factor for patients with LRR in LABC treated with neoadjuvant chemotherapy, mastectomy, and RT [20].

Clinical trials regarding the role and benefit of RT in the management of patients with LABC are sparse. The limited data and guidelines available do suggest that locoregional RT should be employed in post-mastectomy LABC to reduce LRR rates $[17,18,21,22]$. We administered first neoadjuvant chemotherapy, because it is the standard treatment for LABC. Nevertheless, all included patients did not present clinical response, thus we proposed CCRTh. We employed two regimens of CCRTh. The first was based on 5-FU and mitomycin C, because of previously good reported results with this treatment in patients with anal carcinoma [23]. The second regimen was based on cisplatin and gemcitabine, because of good results with this multimodal treatment in head and neck carcinoma and cervical cancer reported in our Institution $[24,25]$. Moreover, we added dexamethasone to these two regimens as an antiemetic drug, and to reduce the risk of radiation neumonitis. Despite the recent knowledge of the higher radiation-neumonitis frequency in patients with lung cancer treated with radiotherapy combined with gemcitabine $[26,27]$, none of enrolled patients developed severe lung or cardiac toxicity as late effects. Moreover, a phase I study showed a reduction of local recurrence rate with the addition of gemcitabine to chemotherapy in unresectable chest wall recurrences [28].

Many issues remain unclear, such as best timing for radiotherapy in relation to surgery. We added CCRTh to standard anthracycline-based chemotherapy to improve local control in this group of patients, obtaining a 5-years DFS of $76.9 \%$ and only one LRR among these 112 patients $(1 \%)$. RT as pre-operative or unique modality has been described for some time with variable outcomes and reports of 5-year clinical cure in different breast-cancer clinical stages [29-31]. In another retrospective study, preoperative RT was administered to 75 patients with tumors $>3 \mathrm{~cm}$ and only $12 \%$ developed LRR, nearly all patients (96\%) underwent conservative surgery with satisfactory cosmetic results [30]. In contrast, in the present study the 
all patients underwent mastectomy, which likely contributed to the lower LRR (1\%) observed in this study.

There are few reports of CCRTh in LABC. Additional experience in treatment type is available for early stage breast carcinoma [31-33]. A retrospective study analyzed 38 patients from five institutional trials with inoperable locoregional disease after primary chemotherapy completion and pre-operative RT treatment, reporting a 5-years DFS of only $35 \%$ and a 5 -year LRR of $27 \%$ for surgically treated patients. In our study we report longer survival and progression-free rates among a larger cohort of patients. Differences between our results and those of the previously mentioned study could be due to differences in the patient populations (our study did not include stage IV patients, while $24 \%$ of patient in the other study had N3 disease) and our use of CCRTh with radiosensitizing agents (mitomycin C (5 mg/m²), 5-fluorouracil $(500 \mathrm{mg} /$ $\left.\mathrm{m}^{2}\right)$, and dexamethasone $(16 \mathrm{mg})$ or cisplatin $(30 \mathrm{mg} /$ $\left.\mathrm{m}^{2}\right)$, gemcitabine $\left(100 \mathrm{mg} / \mathrm{m}^{2}\right)$, and dexamethasone (16 $\mathrm{mg}$ ) weekly for six total courses) during RT.

The success of RT depends on increasing malignant-cell sensitivity to radiation-induced cell kill coupled with a reduction in metastasis phenotypes of these cells. Radiation damage to cells and tissues involve generation of reactive oxygen species and reactive nitrogen species followed by alterations in lipids, DNA, and proteins, which eventually lead to cellular dysfunction or cell death. Alterations in lipid membrane due to peroxidative damage may form a potential initiator of radiosensitizing effects in combination with drugs acting through modulation of membrane associated events involved in apoptosis induction and increasing oxidative damage or by synchronizing cells to a radiosensitive phase of the cell cycle thus causing enhanced killing [34]. This is the rationale for utilizing radiosensitizing agents, and could explain the good pathological response and LRR rates of our study. Nonetheless, this treatment type could increase toxicity as a result of cell damage and apoptosis, but this event was presented in our study patients with the following acceptable profile: grade 1-2 neutropenia in $32.2 \%$; grade $1-2$ anemia in $5.2 \%$, and grade 3 radioepithelitis in $22.4 \%$ of patients. This toxicity is consistent with other retrospective analyses on CCRTh, but in patients with early breast carcinoma $[32,33]$. For example, a retrospective analysis of 106 patients with early disease treated with CCRTh after breast conservative surgery (adjuvant CCRTh) reported grade 3 radioepithelitis in $20 \%$ of patients. Furthermore, when authors compared sequential CT and RT with CCRTh, the latter treatment was superior for 10-year local control (92 vs. $83 \%$ ); however, in this report there were at least four different CCRTh schedules; therefore, it is difficult to conclude which of the four comprises the better treatment regime [33]. Another retrospective study compared 485 patients treated with conservative surgery and post-opera- tive RT with or without concurrent CT, and reported at multivariate analysis that the CCRTh group exhibited a statistically lower recurrence rate with significantly higher grade 2 acute skin toxicity in the concurrent group $(21.2$ vs. $11.2 \%$ of the RT-only group; $p<0.0001$ ) [32]. A phase III study compared concurrent or sequential adjuvant CRT after conservative surgery for early-stage breast cancer, reporting no significant difference for DFS or LRR-free survival; nevertheless in the node-positive subgroup, the 5year LRR-free survival was statistically better in the concurrent arm $(97 \%$ in concurrent $v$ s. $91 \%$ in sequential; $p=$ 0.02 ) corresponding $39 \%$ decreased risk for LRR [35].

In our study, on multivariate analysis, ER negative tumors were associated with higher PCR rates, and poorly differentiated tumors showed a trend for higher pCR rates. A study of 399 pre-operative CT-treated patients with LABC reported that negative ER- and PgR expression and grade 3 are associated with high pCR rates [36]. Two other studies reported similar results concerning the association of absent hormonal receptors (12 times more likely to achieve a pCR) and high histological grade with major pCR rate to neoadjuvant CT in patients with LABC $[9,37]$. Response rates of neoadjuvant CT in LABC are between 5 and $8.7 \%$ with anthracycline-based CT, taxane-containing regimens, or navelbine-containing regimens $[9,37,38]$. In our study, using CCRTh, we found superior PRCB (42\%) and pCR $(29.5 \%)$ than in other series. A phase II study reported similar results to ours, for example, a $27 \%$ pCR rate employing pre-operative CCRTh for breast cancer, in which CT was based on 5-FU and vinorelbine regimens. Therefore, similar to our results, these authors found three pCR-associated factors: histological grade 3 ; absence of hormonal receptors, and high mitotic index [39]. Tumour response to pre-operative CT correlates with outcomes and could identify patients with CT-sensitive micrometastases [7]. We found no association between pCR and DFS. A possible explanation is that tumor response to CCRTh does not reflect sensitivity systemically, but only locally.

A previous report clearly describes the surgical complications of CCRTh-treated patients at our Institution. Three hundred sixty patients were enrolled in this report, of whom $46 \%$ developed wound complications, $17 \%$ surgical site infection, and $16.9 \%$ developed necrosis. The authors found that radiotherapy-induced skin toxicity comprises a risk factor for development of major wound complications. These elevated wound complications may be explained by radiotherapy effects on tissue healing, decrease of vascularity, and induction of tissue-hypoxia and fibrosis, producing necrosis and ulceration [3]. In our analysis, we only included 112 of these 360 patients, because they achieved selection criteria for our analysis. Despite that our series has the larger reported number of CCRTh-treated patients and that treatment was homogeneous (only two regimens of radiosensitizing CT), it 
entertains the limitation of being a retrospective analysis and patient selection was based on clinical response according to the attending physician. Notwithstanding this, we describe valuable information regarding the CCRTh effect and toxicity in patients with high recurrence risk.

\section{Conclusion}

In summary, our results suggest that CCRTh following neoadjuvant chemotherapy possesses good local control with an acceptable toxicity profile, despite the poorer prognosis of patients with inoperable disease after primary chemotherapy in LABC. However, a prospective study needs to be developed to evaluate chemotherapy effectiveness followed by concomitant chemoradiotherapy as induction in the group of patients with high recurrence risk.

\section{Competing interests}

The authors declare that they have no competing interests.

\section{Authors' contributions}

AAM, RMB, EBR, JSZ, TRU, and FLM participated in the design and follow-up of patients. CGB participated in the design, follow-up and radiological treatment of patients. VPS performed the analysis of tumor specimens. OA and DSP performed the statistical analysis and helped to draft the manuscript. FLM conceived of the study, and participated in its design and coordination and helped to draft the manuscript. All authors read and approved the final manuscript.

\section{Acknowledgements}

We thank patients for their precious clinical information.

This work was presented at the ASCO Annual Meeting 2006.

\section{References}

I. Jemal A, Siegel R, Ward E, Hao Y, Xu J, Murray T, Thun MJ: Cancer statistics, 2008. CA Cancer J Clin 2008, 58:7l-96.

2. DGE/SSA: Grupos etáreos. Registro Histopatológico de Neoplasias en México (RHPNM). Mexico City 2003. CD-ROM

3. Ruvalcaba-Limon E, Robles-Vidal C, Poitevin-Chacon A, Chavez-Macgregor M, Gamboa-Vignolle C, Vilar-Compte D: Complications after breast cancer surgery in patients treated with concomitant preoperative chemoradiation: A case-control analysis. Breast Cancer Res Treat. 2006, 95(2):|47-I52.

4. Singletary SE, Allred C, Ashley P, Bassett LW, Berry D, Bland KI, Borgen PI, Clark GM, Edge SB, Hayes DF, Hughes LL, Hutter RV, Morrow $M$, Page DL, Recht A, Theriault RL, Thor A, Weaver DL, Wieand HS, Greene FL: Staging system for breast cancer: revisions for the 6th edition of the AJCC Cancer Staging Manual. Surg Clin North Am 2003, 83:803-819.

5. Giordano SH: Update on locally advanced breast cancer. Oncologist 2003, 8:521-530.

6. Semiglazov VF, Topuzov EE, Bavli JL, Moiseyenko VM, Ivanova OA, Seleznev IK, Orlov AA, Barash NY, Golubeva OM, Chepic OF: Primary (neoadjuvant) chemotherapy and radiotherapy compared with primary radiotherapy alone in stage IIb-IIla breast cancer. Ann Oncol 1994, 5:591-595.

7. Rastogi P, Anderson SJ, Bear HD, Geyer CE, Kahlenberg MS, Robidoux A, Margolese RG, Hoehn JL, Vogel VG, Dakhil SR, Tamkus D, King KM, Pajon ER, Wright MJ, Robert J, Paik S, Mamounas EP, Wol- mark N: Preoperative chemotherapy: updates of National Surgical Adjuvant Breast and Bowel Project Protocols B- 18 and B-27. J Clin Oncol 2008, 26:778-785.

8. Hage JA van der, Velde CI van de, Julien JP, Tubiana-Hulin M, Vandervelden C, Duchateau L: Preoperative chemotherapy in primary operable breast cancer: results from the European Organization for Research and Treatment of Cancer trial I0902. J Clin Oncol 2001, 19:4224-4237.

9. Fernandez-Sanchez M, Gamboa-Dominguez A, Uribe N, Garcia-Ulloa AC, Flores-Estrada D, Candelaria M, Arrieta O: Clinical and pathological predictors of the response to neoadjuvant anthracycline chemotherapy in locally advanced breast cancer. Med Oncol 2006, 23:171-183.

10. Hortobagyi GN, Ames FC, Buzdar AU, Kau SW, McNeese MD, Paulus D, Hug V, Holmes FA, Romsdahl MM, Fraschini G, et al:: Management of stage III primary breast cancer with primary chemotherapy, surgery, and radiation therapy. Cancer 1988, 62:2507-2516.

II. Bonadonna G, Veronesi U, Brambilla C, Ferrari L, Luini A, Greco M, Bartoli C, Coopmans de Yoldi G, Zucali R, Rilke F, et al.: Primary chemotherapy to avoid mastectomy in tumors with diameters of three centimeters or more. J Natl Cancer Inst 1990, 82:1539-1545.

12. National Cancer Data Base, 1998-2004 [http://web.facs.org/ ncdbbmr/ncdbbenchmarks8.cfm]

13. Cooper JS, Guo MD, Herskovic A, Macdonald JS, Martenson JA Jr, AlSarraf M, Byhardt R, Russell AH, Beitler JJ, Spencer S, Asbell SO, Graham MV, Leichman LL: Chemoradiotherapy of locally advanced esophageal cancer: long-term follow-up of a prospective randomized trial (RTOG 85-0I). Radiation Therapy Oncology Group. Jama 1999, 281:1623-1627.

14. Furuse K, Fukuoka M, Kawahara M, Nishikawa H, Takada Y, Kudoh S, Katagami N, Ariyoshi Y: Phase III study of concurrent versus sequential thoracic radiotherapy in combination with mitomycin, vindesine, and cisplatin in unresectable stage III nonsmall-cell lung cancer. J Clin Oncol 1999, I 7:2692-2699.

15. Al-Sarraf M, LeBlanc M, Giri PG, Fu KK, Cooper J, Vuong T, Forastiere AA, Adams G, Sakr WA, Schuller DE, Ensley JF: Chemoradiotherapy versus radiotherapy in patients with advanced nasopharyngeal cancer: phase III randomized Intergroup study 0099. J Clin Oncol 1998, 16:1310-1317.

16. Institute NC: Concurrent chemo-radiation for cervical cancer. Clinical announcement. Washington, DC 1992.

17. Nielsen HM, Overgaard M, Grau C, Jensen AR, Overgaard J: Study of failure pattern among high-risk breast cancer patients with or without postmastectomy radiotherapy in addition to adjuvant systemic therapy: long-term results from the Danish Breast Cancer Cooperative Group DBCG 82 b and c randomized studies. J Clin Oncol 2006, 24:2268-2275.

18. Ragaz J, Olivotto IA, Spinelli J], Phillips N, Jackson SM, Wilson KS, Knowling MA, Coppin CM, Weir L, Gelmon K, Le N, Durand R, Coldman AJ, Manji M: Locoregional radiation therapy in patients with high-risk breast cancer receiving adjuvant chemotherapy: 20-year results of the British Columbia randomized trial. J Natl Cancer Inst 2005, 97: I I6-I26.

19. Chia S, Swain SM, Byrd DR, Mankoff DA: Locally advanced and inflammatory breast cancer. J Clin Oncol 2008, 26:786-790.

20. Huang EH, Tucker SL, Strom EA, McNeese MD, Kuerer HM, Hortobagyi GN, Buzdar AU, Valero V, Perkins GH, Schechter NR, Hunt KK, Sahin AA, Buchholz TA: Predictors of locoregional recurrence in patients with locally advanced breast cancer treated with neoadjuvant chemotherapy, mastectomy, and radiotherapy. Int J Radiat Oncol Biol Phys 2005, 62:35I-357.

21. Gonzalez-Angulo AM, McGuire SE, Buchholz TA, Tucker SL, Kuerer HM, Rouzier R, Kau SW, Huang EH, Morandi P, Ocana A, Cristofanilli $M$, Valero V, Buzdar AU, Hortobagyi GN: Factors predictive of distant metastases in patients with breast cancer who have a pathologic complete response after neoadjuvant chemotherapy. J Clin Oncol 2005, 23:7098-7104.

22. Bristol IJ, Strom EA, Domain D, et al.: Long term locoregional treatment outcomes for patients with inflammatory breast cancer [abstract]. Int J Radiat Oncol Biol Phys 200I, 66:2006.

23. Nigro ND, Seydel HG, Considine B, Vaitkevicius VK, Leichman L, Kinzie J): Combined preoperative radiation and chemotherapy for squamous cell carcinoma of the anal canal. Cancer 1983, 51:1826-1829. 
24. Aguilar-Ponce J, Granados-Garcia M, Villavicencio V, Poitevin-Chacon A, Green D, Duenas-Gonzalez A, Herrera-Gomez A, Luna-Ortiz K, Alvarado A, Martinez-Said H, Castillo-Henkel C, Segura-Pacheco B, De la Garza J: Phase II trial of gemcitabine concurrent with radiation for locally advanced squamous cell carcinoma of the head and neck. Ann Oncol 2004, I 5:301-306.

25. Duenas-Gonzalez A, Cetina-Perez L, Lopez-Graniel C, GonzalezEnciso A, Gomez-Gonzalez E, Rivera-Rubi L, Montalvo-Esquivel G, Munoz-Gonzalez D, Robles-Flores J, Vazquez-Govea E, de La Garza J, Mohar A: Pathologic response and toxicity assessment of chemoradiotherapy with cisplatin versus cisplatin plus gemcitabine in cervical cancer: a randomized Phase II study. Int J Radiat Oncol Biol Phys 2005, 6 I:817-823.

26. Arrieta O, Gallardo-Rincon D, Villarreal-Garza C, Michel RM, Astorga-Ramos AM, Martinez-Barrera L, de la Garza J: High frequency of radiation pneumonitis in patients with locally advanced non-small cell lung cancer treated with concurrent radiotherapy and gemcitabine after induction with gemcitabine and carboplatin. J Thorac Oncol 2009, 4:845-852.

27. Scalliet P, Goor C, Galdermans D, et al.: Gemzar (Gemcitabine) with thoracic radiotherapy-A phase II pilot study in chemonaive patients with advanced non small cell lung cancer (NSCLC). Proc Am Soc Clin Oncol 1998, 17:. (Abstract 1923)

28. Suh WW, Schott AF, Hayman JA, Schipper MJ, Shewach DS, Pierce LJ: A phase I dose escalation trial of gemcitabine with radiotherapy for breast cancer in the treatment of unresectable chest wall recurrences. Breast J 2004, 1 0:204-210.

29. Baclesse F: Five-Year Results in 431 Breast Cancers Treated Solely by Roentgen Rays. Ann Surg 1965, I 6 I: 103- 104.

30. Calitchi E, Kirova YM, Otmezguine Y, Feuilhade F, Piedbois Y, Le Bourgeois JP: Long-term results of neoadjuvant radiation therapy for breast cancer. Int J Cancer 200I, 96:253-259.

31. Huang E, McNeese MD, Strom EA, Perkins GH, Katz A, Hortobagyi GN, Valero V, Kuerer HM, Singletary SE, Hunt KK, Buzdar AU, Buchholz TA: Locoregional treatment outcomes for inoperable anthracycline-resistant breast cancer. Int J Radiat Oncol Biol Phys 2002, 53: I225-1233.

32. Livi L, Saieva C, Borghesi S, Paoletti L, Meattini I, Rampini A, Petrucci A, Scoccianti S, Paiar F, Cataliotti L, Leonulli BG, Bianchi S, Biti GP: Concurrent cyclophosphamide, methotrexate, and 5-fluorouracil chemotherapy and radiotherapy for early breast carcinoma. Int J Radiat Oncol Biol Phys 2008, 71:705-709.

33. Haffty BG, Kim JH, Yang Q, Higgins SA: Concurrent chemo-radiation in the conservative management of breast cancer. Int J Radiat Oncol Biol Phys 2006, 66:1306-1312.

34. Girdhani S, Bhosle SM, Thulsidas SA, Kumar A, Mishra KP: Potential of radiosensitizing agents in cancer chemo-radiotherapy. J Cancer Res Ther 2005, I:|29-|3|.

35. Toledano A, Azria D, Garaud P, Fourquet A, Serin D, Bosset JF, MinyBuffet J, Favre A, Le Floch O, Calais G: Phase III trial of concurrent or sequential adjuvant chemoradiotherapy after conservative surgery for early-stage breast cancer: final results of the ARCOSEIN trial. J Clin Oncol 2007, 25:405-4I0.

36. Colleoni M, Viale G, Zahrieh D, Pruneri G, Gentilini O, Veronesi P, Gelber RD, Curigliano G, Torrisi R, Luini A, et al.: Chemotherapy is more effective in patients with breast cancer not expressing steroid hormone receptors: a study of preoperative treatment. Clin Cancer Res 2004, 1 0:6622-6628.

37. Colleoni M, Viale G, Zahrieh D, Bottiglieri L, Gelber RD, Veronesi P, Balduzzi A, Torrisi R, Luini A, Intra M, Dellapasqua S, Cardillo A, Ghisini R, Peruzzotti G, Goldhirsch A: Expression of ER, PgR, HER I, HER2, and response: a study of preoperative chemotherapy. Ann Oncol 2008, 19:465-472.

38. Tiezzi DG, Andrade JM, Ribeiro-Silva A, Zola FE, Marana HR, Tiezzi MG: HER-2, p53, p2I and hormonal receptors proteins expression as predictive factors of response and prognosis in locally advanced breast cancer treated with neoadjuvant docetaxel plus epirubicin combination. BMC Cancer 2007, 7:36.

39. Bollet MA, Sigal-Zafrani B, Gambotti L, Extra JM, Meunier M, Nos C, Dendale R, Campana F, Kirova YM, Dieras V, Fourquet A: Pathological response to preoperative concurrent chemo-radiotherapy for breast cancer: results of a phase II study. Eur J Cancer 2006, 42:2286-2295.

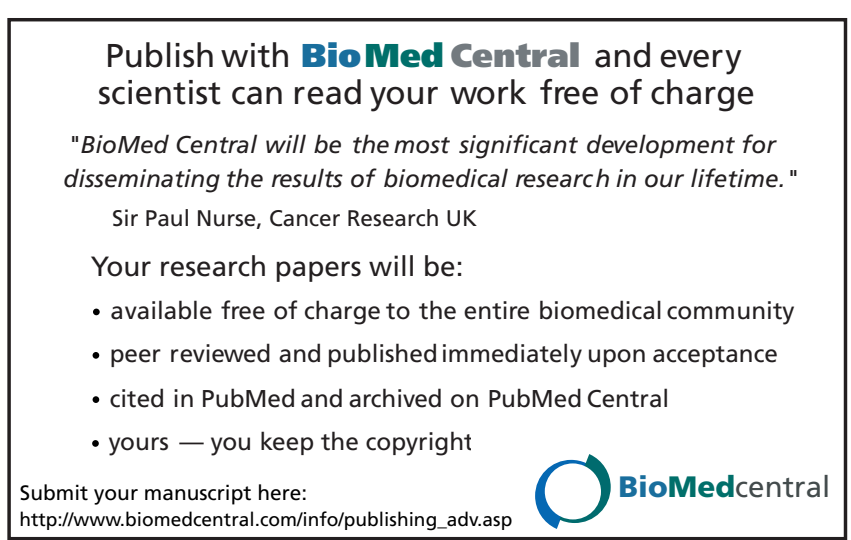

